\title{
ADMISSIBILITY OF EVIDENCE OBTAINED AS A RESULT OF ISSUING AN EUROPEAN INVESTIGATION ORDER IN A POLISH CRIMINAL TRIAL
}

\author{
Hanna Kuczyńska*
}

\begin{abstract}
This article analyses the admissibility of evidence gathered by the Polish procedural authorities as a result of issuing an European Investigation Order, on the basis of provisions implemented due to the adoption on the 3th of April 2014 of the Directive of the European Parliament and of the Council regarding the European Investigation Order in criminal matters. This Directive created a mechanism that allows for transfer of evidence between EU Member States. In this text the question will be answered how to deal with results of investigative measures that have been legally obtained in the executing state but despite acting in accordance with the legality principle by both states, happen to be illegal in the issuing Member State. Another discussed problem is how the rules of admissibility of evidence obtained from the result of issuing an EIO work in Poland - or at least how they should operate. The second discussed issue thus will refer to the current provisions in force in Poland regulating the method of dealing with evidence obtained abroad - that is also with evidence transferred from other Member States. It will be shown that they are unclear and may lead to undesirable results. In addition, suggested changes in Polish law will be proposed.
\end{abstract}

Keywords: admissibility of evidence, evidence in criminal trial, European Investigative Order, Polish criminal trial

\footnotetext{
Dr. habil. Hanna Kuczyńska, Associate Professor, Institute of Law Studies, Polish Academy of Sciences; correspondence address: ul. Nowy Świat 72, 00-330 Warsaw, Poland; e-mail: hkuczynska@gmail.com; https://orcid.org/0000-0002-1446-2244.
} 


\section{INTRODUCTION}

On the 3rd of April 2014, Directive 2014/41/UE of the European Parliament and of the Council of 3 April 2014 regarding the European Investigation Order in criminal matters $(\mathrm{EIO})^{1}$ was adopted. It created a mechanism that allows for transfer of evidence between EU Member States. Implementation of this new mechanism of cooperation has led to several practical problems. This text comprises of two parts - in the first part, general problems resulting from the implementation of EIO will be discussed, especially problems related to general questions of how to deal with the results of investigative measures that have been legally obtained in the executing state, but despite acting in accordance with the legality principle by both states, happen to be illegal in the issuing Member State. A lack of adequate provisions regulating admissibility of evidence acquired in other Member States may become a problem in more Member States, as at present, European Union legal acts do not regulate the problem of admissibility - as the EIO Directive cannot require a judge to admit evidence in trial, neither indicate what evidential value and relevance the evidence should have. Therefore, admission of evidence depends on an independent decision of a national judge under national law.

Secondly, in the text it will be shown how the rules of admissibility of evidence obtained as a result of issuing an EIO work in Poland - or at least how they should operate. The second issue discussed will thus refer to the current provisions in force in Poland regulating the method of dealing with evidence obtained abroad - also with evidence transferred from other Member States as a result of issuing an EIO. It will be shown that they are unclear and may lead to undesirable results.

The text shows how the impact of European criminal law, on the one hand, creates new mechanisms of cooperation that should be incorporated into the law of the Member States, but on the other hand, leads to new problems connected with reconciling this mechanism with the existing legal orders of the Member States - as the cooperation should be both effective and in compliance with the law of the States.

1 OJ UE 130, 1 May, 2014, p. 1-36. 


\section{THE NEW MECHANISM OF EXCHANGE OF EVIDENCE}

Directive 2014/41/UE (the EIO Directive) introduces the principle of mutual recognition in the area of executing investigative measures - according to Article 1(2) of the Directive "Member States shall execute an EIO on the basis of the principle of mutual recognition and in accordance with this Directive". It is a new attitude to transmitting evidence between Member States. The principle of mutual recognition of decisions in criminal matters has become a paradigm of cooperation in criminal matters.

The purpose of mutual recognition of evidence in criminal proceedings across all the Member States was to ensure that evidence gathered in one Member State would be presented before courts throughout the European Union. In the documents issued by the European Union the principle of "free flow of evidence" was mentioned, modeled on the principle of freedom of movement, existing in other areas of Community law. The creators of this concept based it on the assumption that criminal procedures in all the EU Member States are equivalent in the area of conducting investigative measures, and that evidence originating from one State can be used in criminal trials conducted in another Member State ${ }^{2}$. One of the means to implement this principle was to abandon the mechanisms adopted in the Council of Europe in Convention on Mutual Assistance in Criminal Matters between the Member States of the European Union, which was founded on the notion of mutual assistance, letters rogatory and service of writs ${ }^{3}$. Introducing the principle of "free flow of evidence" was not only intended to facilitate cooperation in criminal matters, but was intended to replace the model of "mutual assistance". Such was the intention of the creators of the Directive ${ }^{4}$.

2 See: Programme of measures to implement the principle of mutual recognition of decisions in criminal matters, OJ C 012, 15 January, 2000, p. 2.1.1. Topic discussed in: Hanna Kuczyńska, "Zagadnienia dopuszczalności materiału dowodowego w sprawach karnych na obszarze Unii Europejskiej," Przegląd Prawa Europejskiego i Międzynarodowego, no. 1 (2012): 34 .

Journal of Laws of 1999, No. 76, item 854.

4 See also: Zbigniew Barwina on the Framework decision 2008/978/EU on European Evidence Warrant: Zbigniew Barwina, Zasada wzajemnego uznawania w sprawach karnych (Warsaw: Wolters Kluwer, 2012), 123. 
These are the general assumptions of the EIO Directive. However, although for the time being transfer of evidence is governed by this principle, there are two sides to mutual recognition. The purpose of applying the principle of mutual recognition to transfer of evidence in criminal matters in all Member States was to ensure that:

1. Evidence demanded by one Member State will be automatically transferred from any other Member State which will carry out necessary investigative measures in order to obtain such evidence or will transfer evidence already in their possession;

2. Evidence gathered in one Member State would be admissible before courts throughout the European Union.

The key question that is posed in this text is - on what principles should state authorities base the admissibility of evidence?

In most EU Member States (mostly those of the continental model of criminal trial), the principle of "freedom of evidence" for use in a criminal trial rules ${ }^{5}$. According to this principle, any information that is relevant to the case may be used in criminal trial. This freedom is usually limited by certain conditions that determine the admissibility of evidence during trial. The key issue that should be taken into consideration is that data and information are never automatically a piece of evidence. Only after an assessment by a national court, information or a potential source of evidence becomes evidence in the understanding of procedural law. The procedures of the Member States contain provisions specifying which evidence should be considered admissible or inadmissible. These conditions differ from one State to another, and they cannot be described as "uniform" or even "similar". The most visible and significant differences come into play obviously between the models of admissibility of evidence between families of continental and common law states. Whereas in a continental state the assessment of the value and credibility of evidentiary material takes place at the final stage of a trial (in a holistic assessment), at the same time as passing the judgment on guilt (in a way described as "unitary"

5 Mireille Delmas-Marty and John R. Spencer, eds., European Criminal Procedures (Cambridge: Cambridge University Press, 2004), 394.

See: Kuczyńska, "Zagadnienia dopuszczalności dowodów," 38. 
- in common law literature $)^{7}$, the laws on admissibility of evidence in the common law states are described as "a child of a jury" 8 . In this model of rules of evidence, restrictive rules of admissibility of evidence are intended to protect jurors - who are not professionals - from improperly carried out, illegally obtained or unreliable evidence. The jurors are referred to as the "paradigmatic determining authority", because they decide about facts without prior knowledge of the matter - being a "tabula rasa" organ". The rules of admissibility of evidence are consequently not only a means of protecting the defendant against proving his guilt in a manner inconsistent with the right to a fair trial ${ }^{10}$, but also protecting the jury against adjudicating on the basis of unreliable evidence (by law it is recognized that certain evidence is simply of a "worse quality"11). Moreover, in this model, the admissibility of evidence is decided on both positive and negative premises: first, the evidence must qualify for one of the categories of admissible evidence, and then be subject to negative elimination - in terms of whether the evidence will not adversely affect the reliability of the trial

7 See e.g.: Klaus Rogall, "Grundsatzfragen der Beweisverbote," in Beweisverbote in Ländern der EU und vergleichbaren Rechtsordnungen, ed. Frank Höpfel and Barbara Huber (Freiburg in Breisgau: Edition Iuscrim, 1999), 125-126; Theodor Kleinknecht, "Die Beweisverbote im Strafprozess," Neue Juristische Wochenschrift, no. 19 (1966): 1539; Eduard Kern and Claus Roxin, Strafverfahrensrecht: ein Studienbuch (München: C.H. Beck Verlag, 1987), 141; Jerome Benedict, Le sort des preuves illegales dans le procés pénal (Lausanne: Editions Pro Schola, 1994), 49.

8 James B. Thayer, Preliminary Treatise on Evidence at the Common Law (Boston: Little, Brown and Company, 1898), 47, https://ia800206.us.archive.org/34/items/ cu31924017931712/cu31924017931712.pdf, accessed April, 21, 2021.

9 Mirjan Damaška, The Faces of Justice and State Authority: A Comparative Approach to the Legal Process (Yale: Yale University Press, 1996), 137-138.

10 See Martin Hannibal and Lisa Mountford, The Law of Criminal and Civil Evidence. Principles and Practice (University of Staffordshire: Longman, 2002), 57-84; John R. Spencer, "Evidence," in European Criminal Procedures, eds. Mireille Delmas-Marty and John R. Spencer (Cambridge: Cambridge University Press, 2004), 603; Lydia Waine, Robert May, and Steven Powles, May on criminal evidence (U.K.: Sweet \& Maxwel, 2015), 301; Paul Roberts and Adrian Zuckerman, Criminal Evidence (Oxford: Oxford University Press, 2012), 98.

11 Spencer, "Evidence," 603; Paul Murphy, Murphy on Evidence (Oxford: Oxford University Press, 2008), 10; Thayer, Preliminary Treatise, 1-2; Mirjan Damaška, "Evidentiary barriers to conviction and two models of criminal procedure: a comparative study," University of Pennsylvania Law Review, no. 121 (1973): 519-520. 
or are not illegally obtained, and at the same time they must be relevant to the case and they cannot be subject to prohibitions of admissibility and they must have a weight to decide on the guilt of the accused ${ }^{12}$. Only after this two-stage assessment does information or a potential source of evidence become evidence in the understanding of procedural law. In both models the final decision on admissibility of evidence depends on the judicial balancing of various interests ${ }^{13}$.

Although the models for deciding on admissibility of evidence are shaped so differently, in the aspect of using evidence acquired by issuance of an EIO, the key question is the same in both models: how to resolve the problem of illegal evidence (or evidence acquired in an illegal manner). The attitude towards evidence gathered in other Member States has never been uniform. The lack of uniformity in attitude towards such evidence has been often a point of interest in the literature. Several examples of these tendencies are discussed e.g. by M. Kusak: in an English case $R$. v. Governor of Pentonville Prison ex parte Chinoy ${ }^{14}$ the English court had to decide on the results of illegal telephone tapping obtained in France in violation of French law. It stated that although the evidence was inconsistent with the lex loci, they were in accordance with English law - PACE, section 78 and thus admissible ${ }^{15}$. A Belgian court, on the other hand, required evidence in the form of telephone wiretaps in a situation where it would be incompatible with Belgian law - and after obtaining the results of wiretaps, used it in accordance with lex fori law, admitting them as evidence in the trial ${ }^{16}$. Thus, there are two ways in which evidence may

12 S 78 PACE 1984; see: Hannibal and Mountford, The Law of Criminal, 31-84.

13 Balázs Garamvölgyi, Katalin Ligeti, Anna Ondrejová, and Margarete von Galen, "Admissibility of Evidence in Criminal Proceedings in the EU," Eucrim, no. 3 (2020): 201-208.

14 Discussed by Martyna Kusak, Mutual admissibility of evidence in criminal matters in the EU. A study of telephone tapping and house search (Antwerpen-Apeldoorn-Portland: Maklu, 2016), 173. Published in: [1992] 1 All E.R. 317.

15 Martyna Kusak calls this phenomenon a "reverse phenomenon of process laundering”, see: Kusak, Mutual admissibility, 173.

16 Cour de Cassation, judgment of 2.01.1993 (en cause de Co. D.), published Revue de droit penal (1993), 768 - also discussed by Kusak, Mutual admissibility, 173. 
happen to be illegal: illegal by forum and illegal by way of conducting an investigative measure.

Therefore, it results that there are two main problems before the Member States admitting evidence acquired by means of issuing an EIO:

1. to decide on the results of investigative measures illegal in the issuing Member State,

2. to decide on the results of investigative measures illegal in the executing Member State.

Currently, the EIO Directive attempts to prevent such situations, as it prohibits the issuing of an EIO in a situation where a measure would be illegal under the law of the issuing State, and executing of the EIO, if the act would be inadmissible in the executing State. It reaches this result through two provisions, obliging both the issuing state and the executing state to apply its national law. These could be called the "two sides of legality principle". Moreover, in Article 14(7) it stipulates that "Without prejudice to national procedural rules Member States shall ensure that in criminal proceedings in the issuing State the rights of the defence and the fairness of the proceedings are respected when assessing evidence obtained through the EIO". This provision can be considered to constitute a general rule of admissibility of evidence on the EU level.

Firstly, the issuing authority may only issue an EIO where the condition has been met that the investigative measure(s) indicated in the EIO could have been ordered under the same conditions in a similar domestic case (Article 6(1)(b)). Any alternative solution would lead to a violation of the rule according to which state authorities can act only on the basis of the law. Moreover, it would allow for the use of so called "forum shopping" - allowing for gathering evidence, that is illegal in the issuing state, in a state where it is legal. In consequence it would permit choosing the forum for obtaining evidence at will, based on the lowest minimal procedural guarantees. As a result, the opposite solution would make it possible to apply for illegal evidence in the issuing State to a state where it is legal to conduct it ${ }^{17}$.

17 Hanna Kuczyńska, “Commentary on Article 589x $\$ 2$ CCP," in Kodeks postępowania karnego. Komentarz, ed. Jerzy Skorupka (Warsaw: C.H. Beck, 2020), 1598. 
Secondly, on the other side is the executing state, which must ensure the EIO's execution in the same way and under the same modalities as if the investigative measure concerned had been ordered by an authority of the executing state (Article 9(1)). It is clear that the EIO procedure functions on the basis of the locus regit actum principle - according to which investigative measures are carried out according to the law of the executing state ${ }^{18}$. The courts should take into consideration the requirements of Article 14(7) of the EIO Directive and ensure that rights of the defence and the fairness of the proceedings are respected when admitting such evidence. Nonetheless, the problem still remains of how to deal with results of investigative measures that have been legally obtained in the executing state, but despite obliging the legality principle by both states, happen to be illegal in the issuing Member State - this problem has not yet been resolved by the provisions of the Directive ${ }^{19}$; despite all the efforts of state authorities, evidence might turn out to be gathered through a violation of law. Moreover, the same situation arises when the principle of legality has been breached - M. Kusak calls it a "double admissibility check" where lack of fulfilling the legality principle in the issuing state leads to a refusal to execute the requested investigative measure and lack of fulfilling the legality principle in the executing state leads to refusal to admit the evidence ${ }^{20}$.

Therefore, the above discussed provisions of the Directive, implemented in the Member States, solve only part of the problem of illegal evidence. However, there is still a need to decide on the results of investigative measures that were legally executed in the executing Member State, yet, after transferring their results, appear to be illegal in the issuing Member State.

18 Barbara Nita-Światłowska and Andrzej Światłowski, "Odczytanie w postępowaniu karnym protokołu czynności dowodowej przeprowadzonej przed obcym organem,” Europejski Przeglad Sądowy, no. 2 (2013): 6.

19 See also: Inés Armada, "The European Investigation Order and the Lack of European Standards for Gathering Evidence: Is a Fundamental Rights-Based Refusal the Solution?," New Journal of European Criminal Law, no. 1 (March 2015): 8-31.

20 Martyna Kusak, Dowody zagraniczne. Gromadzenie i dopuszczalność w polskim procesie karnym. Przewodnik z wzorami (Warsaw: Wolters Kluwer, 2019), 32. See also by this Author: "Mutual admissibility of evidence and the European investigation order: aspirations lost in reality," ERA Forum, no. 19 (2019): 399. 
In principle, compliance with the rules of procedure in the executing State is a condition for the use of evidence in the issuing State. However, there is nothing in the Directive that would suggest that the unlawful manner of gathering of evidence in another Member State (as assessed by the issuing authority in accordance with national law) should automatically render evidence inadmissible in the issuing Member State ${ }^{21}$. According to some authors, the mere fact of carrying out an investigative measure in accordance with the law of the executing State (governing the conditions for taking evidence, its form or list of prohibited evidence) implies that the results of this measure must be covered by the principle of mutual recognition and the evidence must be considered admissible ${ }^{22}$. It is hard to agree with such a statement, and it would be difficult to enforce such a rule. Moreover, there is a weakness to this assumption: it is hard to discover the exact meaning of legal provisions of foreign states, which would require appointing an expert on foreign law in every case where any piece of evidence has been acquired in another Member State. In the end, the admissibility of such evidence is left to be assessed by the national courts and in the text below several issues connected with this problem will be discussed on the example of the Polish principles of admissibility of evidence acquired abroad.

\section{THE MAIN ASSUMPTIONS OF THE EIO DIRECTIVE IMPLEMENTATION IN POLAND}

So far, all the mechanisms of cooperation among EU Member States based on the principle of mutual recognition of decisions in criminal matters have been implemented into Polish law by adding subsequent chapters in Section XIII of the Code of Criminal Procedure (CCP $)^{23}$, which governs proceedings in international matters. According to the concept adopted in the Code, the Polish legislator does not mention this principle explicitly in the provisions implementing appropriate instruments of cooperation in

21 Nita-Światłowska and Światłowski, Odczytanie w postępowaniu karnym, 6.

22 Barwina, Zasada wzajemnego uznawania, 123.

23 Act of 6 June 1997 - Journal of Laws 2017, No. 89, item 555. 
criminal matters, implicitly accepting that they are based on cooperation mechanisms adopted by the European Union.

The EIO Directive has been implemented in a similar manner. On the 8th of February 2018 the Act of 10th of January 2018 entered into force ${ }^{24}$. It added new chapters to the Polish Code of Criminal Procedure $62 \mathrm{c}$ and $62 \mathrm{~d}$ CCP which implemented the EIO Directive. Member States were obliged to take the necessary measures to comply with this Directive by 22 May 2017 (according to Article 36 of the EIO Directive) and Poland was one of the last ones to comply.

According to Article 589w $\$ 1$ CCP: "the European Investigation Order is a decision of a court or a public prosecutor issued ex officio or at the request of a party, defence counsel or legal councel, if necessary to conduct or obtain evidence that is placed or may be carried out on the territory of another European Union Member State called 'the executing State' in which the EIO applies". The issuing of an order consists of issuing a decision on carrying out an appropriate investigative measure (e.g. a decision to seize an object, a decision on appointment of an expert) and on completing the form constituting Annex A to the Directive. This means that there is no need to issue a "double" procedural decision, by duplicating the decision issued for the national trial in a decision issued for the purpose of international cooperation. Such regulation presents a departure from the dualistic construction used so far in Polish law, according to which the application of a decision issued in another state is possible only after issuing the appropriate decision provided for by the provisions of the Polish procedure ${ }^{25}$.

The basic assumption of the European Investigation Order is that the executing State must immediately take the steps necessary to comply with the order, in the same way, and in the same manner, as if the decision on the investigative measure had been ordered by the authority of the executing State. This assumption is to enable the construction of a comprehensive system of cooperation that will cover the widest possible catalogue

24 Journal of Laws 2018, item 201.

25 See: Sławomir Steinborn, "Komentarz do art. 589w," in Kodeks postępowania karnego. Komentarz, Vol. II, eds. Jan Grajewski, Lech K. Paprzycki, and Sławomir Steinborn (Warsaw: Wolters Kluwer, 2010), 604. 
of evidence, based on the principle of mutual recognition ${ }^{26}$. The characteristic features of this system are: application to all types of evidence - both those already existing and those that must be obtained by carrying out investigation measures; set and short deadlines for carrying out the requested investigative measures; limited grounds for refusing to execute the order.

For the purpose of this text, the most important issue is that the EIO covers any investigative measure with the exception of the setting up of a joint investigation team and the gathering of evidence within such a team. An EIO can be issued as regards:

1. evidence already in the possession of the competent authorities of the executing State

2. evidence obtained through or as a result of the execution of the EIO to the issuing State - as opposed to the European Evidence Warrant (Framework Decision 2008/978/EU);

The Polish legislator implemented the main assumption of Directive 2014/41/UE deciding that an EIO can be issued "in order to conduct or obtain evidence". This means that such an order may be issued not only when evidence exists and is already available in another Member State, and the only thing that must be done by the authority of the executing State is to transfer this already existing material, but it can also be an impulse to carry out activities aimed at obtaining evidence - that is, investigative measures. Thus, the scope of the activities that may be carried out by the executing State includes evidence that is physically and directly available at the time of issuance of an EIO, as well as evidence not yet in existence - as an EIO may also be used to conduct ("initiate") in another Member State procedural steps (such as for example interviewing witnesses, suspects, accused persons and victims, appointing experts, recording of evidence in real time, intercepting communications and telephone tapping, or monitoring bank accounts, taking evidence of a person from the body, i.e., DNA testing material). An order may also be issued to secure traces and evidence of crime before they are lost, distorted or destroyed ${ }^{27}$.

26 Grzegorz Krysztofiuk, "Europejski nakaz dochodzeniowy," Prokuratura i Prawo, no. 2 (2012): 91.

27 This procedure is now the basis for carrying out such measures, replacing Council Framework Decision 2003/577/JHA of 22 July 2003 on the execution in the European 
The Directive does not define what should be understood under the concept of an "investigative measure", leaving the decision up to Member States as to what they consider to be an investigative measure. This can be any activity carried out to in order to obtain evidence. This is certainly a suitable assumption. It allows for extending the concept of an "investigative measure" to cover all procedural steps and activities leading to obtaining evidence that are fundamentally different in the Member States and not classified in a uniform manner.

The Polish Criminal Procedure Code also does not define the concept of "investigative measures". It can be concluded that these are all procedural activities that lead to obtaining evidence that is admissible in the Polish procedure. This can be all evidence that can be legally obtained and carried out according to Polish law. This assumption complies with the basic assumption of the Directive that the method in which investigative measures will be carried out in the territory of the executing State should be determined by the executing authority in accordance with the national law.

Therefore, the two sides of legality principle are satisfied. Firstly, it is the above-mentioned principle of the legality of executed investigative measures. Secondly, a Polish authority may only request evidence that is legal according to Polish law and legally obtained. Article 589x $\$ 2$ CCP states that it is not possible to issue an EIO if the Polish law does not allow to carry out a specific investigative measure or obtain given evidence. Therefore, it should not be possible to apply for an EIO in a situation where the Polish procedure provides for the existence of rules of exclusion: e.g. in order to carry out an investigative measure aiming at disclosing the circumstances of taking a Crown witness to personal protection or assistance; to interview a witness who is a priest as to facts he learned about in confession, or a defence lawyer about matters covered by the confidentiality principle; to obtain a statement using impermissible methods of interrogation (i.e., the use of coercion or unlawful threat); to apply for

Union of orders freezing property and evidence (Official Journal of the European Union L 196 of 2 August, 2003, p. 45), implemented to the Code of Criminal Procedure under the Act of 7 July 2005 amending the Act - Code of Criminal Procedure and the Act - Code of Procedure in Misdemeanor Cases (Journal of Laws 2005, No. 143, item 1230), which introduced the provisions of the Framework Decision in Chapter 62a and 62b of the Code of Criminal Procedure. 
sources of evidence other than witnesses in order to make use of his/her statements concerning the alleged act made against an expert or a doctor providing him/her medical assistance. It should not be possible to bypass the bans established in the Polish criminal procedure through the use of this instrument. It should also be acknowledged that it is also unacceptable to bypass the existing so called "relative rules of exclusion", for example in order to interview as a witness a person who has exercised the right to refuse to testify in Poland, if in a different Member State such rights are not granted to him $/ h^{28}{ }^{28}$. The exclusionary rules do not exhaust all the rules on legality of evidence: the second level of assessment constitute the rules of admissibility resulting from more general provisions of conventional or constitutional level that define the notion of a fair trial. Therefore, another question should be the assessment of the required piece of evidence in the light of the general rules of admissibility as regulated in these sources and in Article $170 \$ 1 \mathrm{CPP}$ : whether the evidence will be admissible, relevant or possible to acquire.

\section{ADMISSIBILITY OF FOREIGN EVIDENCE IN A POLISH CRIMINAL TRIAL}

This chapter will show some problems resulting from unclear provisions regulating the method of dealing with evidence obtained abroad in the Polish legal order - that is also with evidence transferred from other Member States on the basis of provisions implementing the EIO Directive. In every state existing rules of evidence decide the premises which must be fulfilled by a piece of data in order to "become" evidence. The use of evidence from another state is based on the assumption that data, documents and objects become evidence only after they have been admitted to the trial by the court before which the proceedings are conducted $^{29}$. Collected and transferred, as a result of the issuing of an EIO by the Polish authority, "data and documents" will become "evidence"

28 Kuczyńska, "Commentary," 1598.

29 See: Sabine Gless, "Mutual recognition, judicial inquires, due process and fundamental rights," in European Evidence Warrant: Transnational Judicial Inquiries in the EU, ed. John A.E. Vervaele (Antwerpen-Oxford: Intersentia, 2005), 123. 
only after its admission at trial as evidence by a procedural authority. The key question for the issue raised in this text is the question on what principles this authority should base the decision on admissibility of evidence. There are two regimes of admissibility of evidence in the Polish criminal trial:

1. Domestic regime;

2. Regime applicable to evidence obtained abroad (art. 587 CCP).

The regime of admissibility of evidence applicable to evidence obtained abroad is based on the provision of Article 587 CCP, which reads as follows: "The official records of inspections, interviews of the suspects and accused persons, witnesses or experts, or records of other investigative measures prepared upon a request from a Polish court or state prosecutor, by the courts or state prosecutors of foreign states or by organs under their supervision, may be read aloud at the hearing according to the principles prescribed in Articles 389, 391 and 393" (these are the general rules of admission of indirect evidence at trial). Admission of evidence gathered abroad may take place provided that "the manner of performing these actions, does not conflict with the principles of the legal order in the Republic of Poland".

This solution equally has advantages and disadvantages. Among the first positive elements, the most important is the limited scope as to the level of formal requirements. It is agreed in the Polish jurisprudence and doctrine that the notion of "principles of the legal order" cannot be understood as a requirement to follow detailed provisions regarding the conduct of procedural acts (formally). It is a type of "clause d'ordre public" - a clause of a general nature. According to the opinion expressed by the Polish Supreme Court, the provisions governing the performance of particular investigative measures concern only the manner of conducting them in proceedings pending in Poland, and it cannot be required that foreign authorities should follow them when conducting an investigative measure. The legality of telephone wiretapping carried out by the authorities of a foreign state, even if they are to be incorporated into a Polish trial, as part of pending proceedings, should be assessed in accordance with Article 587 CCP, if the manner in which they are carried out does not contradict the principles of the legal order in the Republic of Poland. Thus, the expression "principles of the legal order of the Republic of Po- 
land" cannot be understood as the preservation of detailed provisions regarding the conduct of procedural actions. By referring to the "principles of the legal order" it was clearly indicated that these are rules of a more general nature, such as the rights of the defense, the right to refuse to provide explanations, or the prohibition of obtaining evidence under conditions excluding freedom of expression ${ }^{30}$. Moreover, by introducing this general clause it allows for admission of evidence obtained according to locus regit actum principle and makes it unnecessary to refer to forum regit actum principle ${ }^{31}$ - that it is not necessary to oblige the executing state to apply certain formalities and conditions while carrying out the required investigative measure.

The most serious disadvantage is, however, the limited scope of application of Article 578 CCP: only evidence in the form of "official records" can be admitted on the basis of this provision and only according to the principles prescribed in Articles 389, 391 and 393 CCP.

Having established that there is a special regime for admitting evidence gathered abroad, a question must be posed: how then should the Polish authorities issuing an EIO deal with the evidentiary material transferred from the executing Member State? There is no provision that could answer this question - neither in the Polish CCP nor the Directive. As it is a new mechanism of cooperation the literature or jurisprudence offers no answer either ${ }^{32}$. The hierarchy of legal acts (and Article $615 \$ 2$ of the Code of Criminal Procedure) is not helpful here either, because the Directive itself is not hierarchically superior to the Polish law (the supremacy of EU law can be discussed as regards national laws, but this is not the place for such considerations), and secondly, it says nothing on the subject of how to admit evidence from other Member States.

30 See: Polish Supreme Court, Judgment of 19 September 2000, Ref. No. V KKN 331/00, published LEX no. 50992 and Polish Supreme Court, Decision of 8 February 2006, Ref. No. III KK 370/04, published LEX no. 176060 - similarly: Piotr Hofmański, Elżbieta Sadzik, and Kazimierz Zgryzek, Kodeks postępowania karnego. Komentarz (Warsaw: C.H. Beck, 2012), 475.

31 Barwina, Zasada wzajemnego uznawania, 274.

32 Although see: Armada, The European, 8, who proposes the most flexible rule of admitting evidence if they pass the fundamental rights compliance test. 
There are three possible solutions (theoretically), that can be derived from the existing legal order:

1. Apply Article 587 CCP only to "official records" - the rest of the evidence may be admitted on the basis of national regime;

2. Apply national regime - to all types of evidence gathered in other Member State as a result of an EIO;

3. Apply Article $587 \mathrm{CCP}$ per analogiam - also to other types of evidence as "official records" - this provision would become the basis for admitting all trans-border evidence from other EU Member States.

Regarding the first solution, one should keep in mind that it would allow applying Article 587 CCP only to "official records". This solution could result in the existence of two regimes of admissibility of evidence in the same proceedings. Outside the scope of Article 587 CCP evidence other than "official records" would be left out, as with e.g. all the official documents and statements, results of monitoring bank accounts, or even an expert opinion. In consequence, this "double regime" of rules of admissibility of foreign evidence would lead to an unclear scope of the above-mentioned provision, and most of all - in a lack of predictability for other Member States. Moreover, this solution leads to such a result that the admissibility only of some evidence gathered abroad and on the territory of Poland is much wider than others. However, given the present state of national rules of admissibility of evidence, it is hard to say which one has a wider scope. Moreover, it is also claimed that the applicability of Article 578 CCP depends also on conditions as set out in the above-mentioned Articles: 389, 391 and 393 CCP - the rules of admitting indirect evidence which apply in certain situations, only when the direct evidence (witness) are not available ${ }^{33}$. The third condition, as defined in this Article, is that the records must be "prepared upon a request from a Polish court or state prosecutor". Therefore, there are opinions, according to which this expression cannot be identified with "obtained upon a request" ${ }^{34}$, as evi-

33 Nita-Światłowska and Światłowski, "Odczytanie w postępowaniu karnym," 7.

34 Michał Płachta, "Komentarz do art. 578," in Kodeks postępowania karnego. Komentarz, eds. Jan Grajewski, Lech K. Paprzycki, and Michał Płachta (Kraków: Zakamycze, 2003), 494-495; differently: Arkadiusz Lach, Europejska pomoc prawna w sprawach karnych (Toruń: TNOiK, 2007), 296-298. 
dence already existing and only transferred upon an issuance of an EIO is not "prepared" upon request - but only "obtained". Thus, the formulation of this provisions would narrow down the possible application of Article $578 \mathrm{CCP}$ to results of EIOs that were not existing at the moment of issuing an EIO. However, the last condition was rightly rejected in the jurisprudence of the Polish Supreme Court - it concluded that this provision should be understood as applicable also to records "obtained on request" 35 . From all the above mentioned reasons this solution does not seem to be the right one.

As to the second solution, that is applying the domestic regime equally to all types of evidence also to these obtained abroad, it must be said that in the present moment the rules of admissibility of national evidence are a "source of constant confusion of both doctrine and courts" ${ }^{6}$. According to Article 168a CCP "Evidence cannot be considered inadmissible only on the grounds that it was obtained in violation of the provisions of the proceedings or by means of an offense referred to in Article $1 \S 1$ of the Criminal Code, unless the evidence was obtained in connection with the performance of official duties by a state functionary as a result of: murder, deliberate damage to health or imprisonment". There are at least 3 different interpretations of Article 168a CCP in the literature ${ }^{37}$. One has to bear in mind the total irrationality of the most obvious and literal interpretation of Article 168a CCP - it indicates the prohibition of deciding that evidence is not admissible only because it is illegal, i.e. was obtained by means of a prohibited act. As a result of this interpretation there would be no procedural sanctions for violating the procedural rules of collecting evidence, thus the rules set out in the CCP could be considered to be unnecessary. It is to be assumed that courts should not apply this provision if the method of gathering or presenting evidence violates Article 7 of the Constitution of the Republic of Poland and Article 6 of the ECHR. Also it is possible to apply other norms of the Code

35 Polish Supreme Court, Ref. No. V KKN 126/99, published Lex no. 51664; see also: Sławomir Steinborn, Komentarz do artykutu 578 kodeksu postępowania karnego, thesis 8, Lex.

36 This issue is discussed extensively by: Dagmara Gruszecka, "W kwestii interpretacji znowelizowanego przepisu art. 168a," Palestra, no. 1-2 (2017): 1.

37 Presented i.a. by Gruszecka, "W kwestii interpretacji," 2. 
- Article $170 \$ 1(1)$ CCP which stipulates "An application for evidence is denied if the taking of evidence is inadmissible" - in order to exclude the possibility to admit illegal evidence ${ }^{38}$. The Supreme Court concluded that this provision may not constitute the legal basis to admit evidence obtained in breach of procedural provisions or by means of a prohibited act, if admitting of such evidence would render the process unfair within the meaning of Art. 6 of the Convention - and this interpretation should be considered to be valid ${ }^{39}$. At the same time it must be stressed that in the opinion of the Court not all evidence obtained in breach of the ECHR (for example, breach of privacy or protection of the private home) is automatically excluded from the criminal proceedings. From the ECtHR case law it results that only evidence, the use of which could violate the integrity of the trial or the rule of law, must be excluded ${ }^{40}$.

The consequence of this concept would be the admission of evidence on the basis of general rules regarding admissibility of indirectly presented evidence: Articles 389, 391 and 393 CCP. The last provision is particularly important as it allows the reading aloud at trial of records on inspections, searches and retaining objects, as well as the opinions of experts, scientific institutes, establishments or institutions, criminal records of persons, outcomes of inquiry in the community, and any official documents, submitted in the course of preparatory or judicial proceedings as well as any private documents prepared outside the criminal proceedings, particularly statements, publications, letters and notes. Using this solution makes Article 578 dispensable in the EIO procedure ${ }^{41}$. It should be also remembered, that rules of admitting of indirect evidence should be

38 Used in jurisprudence of the Appellate Court in Wrocław, Judgment of 27 April 2017, Ref. No II AKa 213/16, published in: OSA 2017/4/3-63.

39 Polish Supreme Court, Decision of 26 June 2019, Ref. No. IV KK 328/18, published OSNKW 2019/8, pos. 46.

40 Judgment of ECHtR of 1 June 2010, Case Gäfgen v. Germany, application no. 22978/05, paras 98-99, hudoc.int; Judgment of ECHtR of 26 April 2007, Case Popescu $v$ Romania, application nos. 49234/99 and 71525/01, para 106, hudic.int; Judgment of ECHtR of 9 June 1998, Case Teixeira de Castro v Portugal, application no. 25829/94, hudoc.int. Cases discussed in: Garamvölgyi, “Admissibility of Evidence,” 204.

41 See: Sławomir Steinborn, Komentarz do artykutu 578 kodeksu postępowania karnego, thesis 9, Lex. 
in compliance with the jurisprudence of the European Court of Human Rights - especially established in the case Jakubczyk $v$. Poland ${ }^{42}$. So far, the second solution seems to be the most suitable.

The third solution, applying Article 587 CCP per analogiam leads to the rejection of a simple interpretation based solely on language interpretation. As a result, these provisions could be used to a unified approach to all the evidence gathered in the other Member States. Moreover, a systemic interpretation could be used - both sets of provisions, implementing the EIO and Article 587 CCP are situated in the same chapter XIII CCP dealing with international cooperation in criminal matters. However, there are serious doubts as to the possibility of applying procedural provisions per analogiam - even though this solution operates not strictly to the detriment of the accused, it would still allow for such a possibility for the accusation ${ }^{43}$. Besides, it is sometimes hard to say before conducting an investigative measure whether its results will be in favour of or against the accused. Therefore, also this solution should be rejected.

As it has been shown above, there is a lacuna - there should be a provision regarding the proper basis for the admission of the evidentiary material obtained in result of issuing an EIO - but there is currently none available in the Polish legal order. None of the above-mentioned solutions can be adopted without any doubts. The most natural model at the time being would be to use national rules of admissibility, as lack of fulfilling technical formalities does not render evidence automatically inadmissible in Polish criminal procedure - with a reservation made below. As a result, it will be a task for the Polish courts to assess the admissibility of evidence gathered through the issuance of an EIO. At the moment, they can use all of the concepts presented above. In fact, they apply the simplest option - they disclose all documents and evidence acquired from another Member State as are included in the file of the case, without providing a legal basis. The functional practice of the EIO Directive shows that state authorities do not hesitate to admit evidence obtained as the result of issuing an EIO on the basis of national rules of admissibility of evidence.

42 Judgment of ECHtR of 10 May 2011, Case Jakubczyk v. Poland, application no. $17354 / 04$, hudoc.int.

43 See: Lach, Europejska pomoc prawna, 298. 
This does not mean that it is done "ruthlessly" - authorities use the rule that allows the requesting authority to determine the formalities and procedures that may contribute to allowing evidence sought admissible before its courts - as provided in Article 9(2) of the EIO Directive. When completing the form of an EOI, it should also be remembered that in Part I of Form A, which describes "Formalities and procedures requested for the execution", the issuing authority could indicate which formalities it is requesting to be complied with. The most common "formality" that is requested by Polish prosecutors is reading out "instructions" (pouczenie) for a suspect or a witness that contain a list of procedural rights. When such a document is signed by an interviewee it signifies that $s /$ he has knowledge of these procedural rights. As a matter of fact, this formality is automatic in every case where a Polish prosecutor issues an EIO in order to obtain depositions. The Polish authorities produce a list of formalities that should be followed during the investigative activity - but only those that they see as the most important for the procedural guarantees. In the end they admit the results of the EIO without further questions. This interpretation is admissible in the light of the requirements of Article 14(7) of the EIO Directive: it allows for admitting evidence in most cases, where only the violation of the right of the defence and the fairness of the proceedings prohibit the admissibility of evidence. Also the present jurisprudence of the Supreme Court confirms this attitude. Therefore, the basic rule of admissibility of the EIO results applied by the Polish issuing authorities could be based both on the national rules on admissibility read in the light of Article 14(7) and the test of Article 6 of the Convention - which requires taking into consideration the present jurisprudence of the Court.

\section{CONCLUSIONS}

As it has been shown the EIO Directive provides only a limited scope of mutual recognition: evidence demanded by one Member State are automatically obtained from any other Member State which will carry out necessary investigative measures in order to obtain such evidence, or will transfer evidence already in its possession. This is only stage one of the mutual recognition of evidence in criminal matters on the basis of the prin- 
ciple of mutual recognition. It must also be borne in mind that applying the principle of mutual recognition to the "free flow of evidence" between Member States does not in fact mean the "admission" of evidence, but only the "recognition of an EIO" issued in another Member State.

However, at present, the European Union legal acts cannot ensure that the evidence will actually be admitted at trial. The purpose of the EIO Directive was not to unify or harmonize European legislation in the area of investigative activities or rules of evidence - nor in the area of admissibility of evidence ${ }^{44}$. Indeed, the EIO Directive does not provide for any mechanism to ensure the admission of evidence transferred on its basis. Should it provide for such a mechanism? The answer is not obvious. The Directive cannot require a judge to admit evidence at trial, nor indicate what evidential value and relevance the evidence has. Each time, the admission of evidence depends on an independent decision by a national judge under national law. Therefore, according to the Polish procedure, after completing the evidentiary proceedings, evidence "imported" from other Member States will be subject to the rules proper for assessing first the admissibility of evidence stipulated in Article $17 \$ 1 \mathrm{CCP}$ and then the value of evidence as provided in Articles: 4 CCP, $5 \$ 2$ CCP, 7 CCP and 410 CCP, equally with all other evidence. All rules of exclusion of evidence should also be applied. However, although the EU law cannot force the judge to admit evidence, it should give clear premises on which the judge could base that decision, that would allow for a coherent application of rules of admissibility in all the Member States.

The basic guarantee of compliance with certain standards is the principle according to which the authority collecting evidence at the request of another state should collect this evidence only in accordance with the national law. Another guarantee that can be used is expressed in Article 9(2) of the Directive, which obliges the executing authority to comply with the formalities and procedures expressly indicated by the issuing authority unless otherwise provided in this Directive and provided that such formalities and procedures are not contrary to the fundamental principles of

44 Marcello Daniele, "Evidence Gathering in the Realm of the European Investigation Order: From National Rules to Global Principles," New Journal of European Criminal Law, no. 1 (June 2015): 179-194. 
law of the executing State ${ }^{45}$ (such as affixing a document with an official seal, the presence of a representative of the requesting State, or recording the date and time to obtain continuity of documentary evidence) and Article 14(7) of the Directive. The executing State is obliged under the Directive to the fullest extent possible, to take claims into account when carrying out the investigative measure. This constitutes an exception as a departure from the principle of locus regit actum for forum regit actum principle ${ }^{46}$. Also, the Directive regulates the manner of performing particular types of investigative activities, which are characterized by increased interference in the rights of an individual, or constitute a special facilitation of the performed activity. Regulating the specific form and course of such investigative measures is intended to allow states, if not to harmonize the provisions governing these operations, to at least interpret a common standard relating to the execution of the European Investigation Order in this respect. The Directive provides a standardized course for such investigative measures, including the minimum guarantees of their participants (see Annex A of the Directive, section $\mathrm{H} 4$ to H7) ${ }^{47}$. Moreover, the present state of affairs can be also seen as conferring an element of flexibility that allows the EIO to function without obstacles and the need for any further harmonization. Not only in Poland may state authorities claim that there are no serious problems with admissibility of evidence.

As regards the issue of implementation of the EIO in Poland, the crucial problem is that there are currently two systems of admissibility of evidence: "domestic" and "foreign", where "foreign" has a limited scope of application. The legislator's attention should be drawn to the fact that it is necessary to clarify the situation of evidence obtained by issuing an European Investigation Order, because at the moment this situation is unclear. One can only propose ways to solve this situation on the grounds of doctrine, based on incomplete statutory solutions.

45 See earlier (than the EIO Directive) proposals of Aleksandra Soltysińska, in: Gwidon Jaworski and Aleksandra Sołtysińska, Postępowanie w sprawach karnych ze stosunków międzynarodowych. Komentarz (Warsaw: Wolters Kluwer, 2010), 51.

46 Barwina, Zasada wzajemnego uznawania, 274.

47 Kuczyńska, "Commentary," 1594. 
De lege ferenda it should be postulated to introduce clear and precise regulation, which would indicate on what terms the evidence gathered as a result of issuing the EIO should be admitted. A uniform system is needed, predictable and clear, setting the rules of admissibility of evidence obtained as a result of the issuing of an EIO - both in the Polish CCP and/or in a EU Directive. It is clear that the present provision of Article 587 CCP is outdated and maladjusted to the present needs of international cooperation in criminal matters - especially in the area of the EU. Such provisions should decide that evidence obtained as the result of issuing an EIO should be admissible if the EIO was issued in accordance with Polish law and the investigative measure was conducted in accordance with the executing state law. It is clear at the same time, that the rules of admissibility must remain at a certain level of generality, and the main test of admissibility should be in compliance both with national rules and Article 6 of the ECHR. It cannot be either forgotten that the rules of admissibility of national evidence in Member States are far from clear and precise.

For the time being, most authors assume that "essentially relations between the requesting State and the executing State in the Directive are based on "blind recognition", founded on the identical trust of the States without any possibility to "contradict" the selection of the procedural form of collection of the evidence according to discretion of the executing State" 48 . At the same time, it is worth mentioning that there are proposals to adopt a directive regarding the admissibility of evidence in the territory of the European Union. There are voices in the literature in favour of a new legislative proposal based on Art. 82(2), subsection 2 TFEU laying down common rules for admissibility of evidence in criminal proceedings. Such a proposal needs to acknowledge the case law of the CJEU as to the in-

48 See: Raimundas Jurka and Jolanta Zajančkauskienė, "Movement of Evidence in the European Union: Challenges for the European Investigation Order," Baltic Journal of Law \& Politics, A Journal of Vytautas Magnus University, no. 2(9) (2016): 75 and also the cited article by: Lorena Bachmaier Winter, "European Investigation Order for obtaining evidence in the criminal proceedings. Study of the proposal for European Directive," Zeitschrift für Internationale Strafrechtsdogmatik, http://www.zis-online.com/dat/ artikel/2010_9_490.pdf, accessed December 21, 2020, p. 586. 
dependence of judicial authorities and as to respect for the rule of law ${ }^{49}$. It would regulate the rules for the admission of evidence obtained in other Member States - whether in a general form or just requiring compliance with certain minimum standards - for example, that evidence obtained in an illegal manner would always be inadmissible. The basic problem that would have to be resolved by such a directive is the difference between two families of law - in which opposing principles govern the admissibility of evidence: the general admissibility of evidence in continental states and the admissibility of specific types of evidence only in the common law states. However, given the considerations presented above, it seems that such a directive would be perceived as limiting the powers of national judges to admit evidence.

\section{REFERENCES}

Armada, Inés. "The European Investigation Order and the Lack of European Standards for Gathering Evidence: Is a Fundamental Rights-Based Refusal the Solution?." New Journal of European Criminal Law, no. 1 (March 2015): 8-31.

Bachmaier Winter, Lorena. "European Investigation Order for obtaining evidence in the criminal proceedings. Study of the proposal for European Directive." Zeitschrift für Internationale Strafrechtsdogmatik. Accessed December 21, 2020. http://www.zis-online.com/dat/artikel/2010_9_490.pdf.

Barwina, Zbigniew. Zasada wzajemnego uznawania $w$ sprawach karnych (The principle of mutual recognition in criminal matters). Warsaw: Wolters Kluwer, 2012. Benedict, Jerome. Le sort des preuves illegales dans le procés pénal. Lausanne: Editions Pro Schola, 1994.

Damaška, Mirjan. "Evidentiary barriers to conviction and two models of criminal procedure: a comparative study." University of Pennsylvania Law Review, no. 121 (1973): 506-589.

Damaška, Mirjan. The Faces of Justice and State Authority: A Comparative Approach to the Legal Process. Yale: Yale University Press, 1996.

49 See: Andrea Ryan, Towards a System of European Criminal Justice. The problem of admissibility of evidence (London and New York: Routledge, 2014), 249; Garamvölgyi, "Admissibility of Evidence," 204. 
Daniele, Marcello. "Evidence Gathering in the Realm of the European Investigation Order: From National Rules to Global Principles." New Journal of European Criminal Law, no. 1 (June 2015): 179-194.

Delmas-Marty, Mireille, and John. R. Spencer, eds. European Criminal Procedures. Cambridge: Cambridge University Press, 2004.

Garamvölgyi, Balázs, Katalin Ligeti, Anna Ondrejová, and Margarete von Galen. "Admissibility of Evidence in Criminal Proceedings in the EU." Eucrim, no. 3 (2020): 201-208.

Gless, Sabine. "Mutual recognition, judicial inquires, due process and fundamental rights." In European Evidence Warrant: Transnational Judicial Inquiries in the EU, edited by John A.E. Vervaele, 121-29. Antwerpen-Oxford: Intersentia, 2005.

Gruszecka, Dagmara. "W kwestii interpretacji znowelizowanego przepisu art. 168a (Regarding the interpretation of the revised provision of art. 168a)." Palestra, no. 1-2 (2017): 60-78.

Hannibal, Martin, and Lisa Mountford. The Law of Criminal and Civil Evidence. Principles and Practice. University of Staffordshire: Longman, 2002.

Hofmański, Piotr, Elżbieta Sadzik, and Kazimierz Zgryzek. Kodeks postępowania karnego. Komentarz (Code of Criminal Procedure. Commentary). Warsaw: C.H. Beck, 2012.

Jaworski, Gwidon, and Aleksandra Sołtysińska. Postępowanie w sprawach karnych ze stosunków międzynarodowych. Komentarz (Criminal proceedings in international relations. Commentary). Warsaw: Wolters Kluwer, 2010.

Jurka, Raimundas, and Jolanta Zajančkauskienè. "Movement of Evidence in the European Union: Challenges for the European Investigation Order." Baltic Journal of Law \& Politics, A Journal of Vytautas Magnus University, no. 2(9) (2016): 56-84.

Kern, Eduard, and Claus Roxin. Strafverfahrensrecht: ein Studienbuch. München: C.H. Beck Verlag, 1987.

Kleinknecht, Theodor. "Die Beweisverbote im Strafprozess." Neue Juristische Wochenschrift, no. 19 (1966): 1537-1546.

Krysztofiuk, Grzegorz. "Europejski nakaz dochodzeniowy (European Investigation Order)." Prokuratura i Prawo, no. 2 (2012): 81-106.

Kuczyńska, Hanna. "Zagadnienia dopuszczalności materiału dowodowego w sprawach karnych na obszarze Unii Europejskiej (Issues of admissibility of evidence in criminal matters in the area of the European Union)." Przeglad Prawa Europejskiego i Międzynarodowego, no. 1(28) (2012): 23-52. 
Kuczyńska, Hanna. “Commentary on Article 589x \$2 CCP.” In Kodeks postępowania karnego. Komentarz (Code of Criminal Procedure. Commentary), edited by Jerzy Skorupka, 1578-1658. Warsaw: C.H. Beck, 2020.

Kusak, Martyna. Mutual admissibility of evidence in criminal matters in the EU. A study of telephone tapping and house search. Antwerpen-Apeldoorn-Portland: Maklu, 2016.

Kusak, Martyna. Dowody zagraniczne. Gromadzenie i dopuszczalność w polskim procesie karnym. Przewodnik z wzorami. Warsaw: Wolters Kluwer, 2019.

Kusak, Martyna. "Mutual admissibility of evidence and the European investigation order: aspirations lost in reality." ERA Forum, no. 19 (2019): 391-400.

Lach, Arkadiusz. Europejska pomoc prawna w sprawach karnych (European mutual assistance in criminal matters). Toruń: TNOiK, 2007.

Murphy, Paul. Murphy on Evidence. Oxford: Oxford University Press, 2008.

Nita-Światłowska, Barbara, and Andrzej Światłowski. "Odczytanie w postępowaniu karnym protokołu czynności dowodowej przeprowadzonej przed obcym organem (Incorporating in criminal proceedings official records taken before a foreign authority)." Europejski Przeglad Sądowy, no. 2 (2013): 4-11.

Płachta, Michał. "Komentarz do art. 578." In Kodeks postępowania karnego. Komentarz (Code of Criminal Procedure. Commentary), edited by Jan Grajewski, Lech K. Paprzycki, and Michał Płachta. Kraków: Zakamycze, 2003.

Rogall, Klaus. "Grundsatzfragen der Beweisverbote." In Beweisverbote in Ländern der EU und vergleichbaren Rechtsordnungen, edited by Frank Höpfel, and Barbara Huber, 119-148. Freiburg in Breisgau: Edition Iuscrim, 1999.

Roberts, Paul, and Adrian Zuckerman. Criminal Evidence. Oxford: Oxford University Press, 2012.

Ryan, Andrea. Towards a System of European Criminal Justice. The problem of admissibility of evidence. London and New York: Routledge, 2014.

Steinborn, Sławomir. "Komentarz do art. 589w." In Kodeks postępowania karnego. Komentarz (Code of Criminal Procedure. Commentary), Vol. II, edited by Jan Grajewski, Lech K. Paprzycki, and Sławomir Steinborn. Warsaw: Wolters Kluwer, 2010.

Thayer, James B. Preliminary Treatise on Evidence at the Common Law. Boston: Little, Brown and Company, 1898.

Waine, Lydia, Robert May, and Steven Powles. May on criminal evidence. U.K.: Sweet \& Maxwel, 2015. 